\title{
Listeriosis prevention knowledge among pregnant women in the USA
}

\author{
FOLASHADE OGUNMODEDE ${ }^{1}$, JEFFERY L. JONES ${ }^{2}$, JONI SCHEFTEL ${ }^{1}$, \\ ELIZABETH KIRKLAND ${ }^{2}$, JAY SCHULKIN ${ }^{3}$, \& RUTH LYNFIELD ${ }^{1}$ \\ ${ }^{1}$ Division of Infectious Disease Epidemiology, Prevention and Control, Minnesota Department of Health, Minneapolis, MN, \\ USA, ${ }^{2}$ Division of Parasitic Diseases, National Center for Infectious Diseases, Centers for Disease Control and Prevention, \\ Atlanta, GA, USA, and ${ }^{3}$ Department of Research, American College of Obstetricians and Gynecologists, Washington, DC, \\ USA
}

\begin{abstract}
Background: Listeriosis is a food-borne disease often associated with ready-to-eat foods. It usually causes mild febrile gastrointestinal illness in immunocompetent persons. In pregnant women, it may cause more severe infection and often crosses the placenta to infect the fetus, resulting in miscarriage, fetal death or neonatal morbidity. Simple precautions during pregnancy can prevent listeriosis. However, many women are unaware of these precautions and listeriosis education is often omitted from prenatal care.

Methods: Volunteer pregnant women were recruited to complete a questionnaire to assess their knowledge of listeriosis and its prevention, in two separate studies. One study was a national survey of 403 women from throughout the USA, and the other survey was limited to 286 Minnesota residents.

Results: In the multi-state survey, 74 of 403 respondents (18\%) had some knowledge of listeriosis, compared with 43 of 286 (15\%) respondents to the Minnesota survey. The majority of respondents reported hearing about listeriosis from a medical professional. In the multi-state survey, $33 \%$ of respondents knew listeriosis could be prevented by not eating delicatessen meats, compared with $17 \%$ in the Minnesota survey $(p=0.01)$. Similarly, $31 \%$ of respondents to the multi-state survey compared with $19 \%$ of Minnesota survey respondents knew listeriosis could be prevented by avoiding unpasteurized dairy products $(\mathrm{p}=0.05)$. As for preventive behaviors, $18 \%$ of US and $23 \%$ of Minnesota respondents reported avoiding delicatessen meats and ready-to-eat foods during pregnancy, whereas $86 \%$ and $88 \%$, respectively, avoided unpasteurized dairy products.

Conclusions: Most pregnant women have limited knowledge of listeriosis prevention. Even though most respondents avoided eating unpasteurized dairy products, they were unaware of the risk associated with ready-to-eat foods. Improved education of pregnant women regarding the risk and sources of listeriosis in pregnancy is needed.
\end{abstract}

Keywords: Listeriosis, ready-to-eat foods, risk factors, survey

\section{Introduction}

In normal, healthy adults, Listeria monocytogenes, a Gram-positive intracellular rod, is a relatively uncommon cause of self-limiting febrile gastrointestinal illness $[1,2]$. However, in pregnant women, the elderly, neonates and immunocompromised individuals, severe bacteremia may occur with spread of infection to the meninges, lungs, liver, lymphatic system and placenta. Pregnant women are 20 times more likely than healthy adults to become infected with L. monocytogenes, and they account for $27 \%$ of all cases of listeriosis [3]. Pregnant women are particularly susceptible to intracellular pathogens such as L. monocytogenes because of a progesteroneinduced down-regulation of cell-mediated immunity. [4] Vertical transmission following bacteremia is a frequent occurrence, because L. monocytogenes exhibits tropism for the fetoplacental unit ${ }^{5}$. Perinatal disease may manifest as granulomatosis infantisepticum, a disseminated infection usually resulting in intrauterine death. Neonatal listeriosis may present as early-onset neonatal sepsis in the first week of life, or as late-onset meningitis after the first week of life. The clinical picture is very similar to invasive group B streptococcal disease $[5,6]$. L. monocytogenes is primarily a food-borne pathogen, although zoonotic and nosocomial transmission have also been docu-

Correspondence: Ruth Lynfield, Minnesota Department of Health, 717 Delaware St SE, Minneapolis, MN 55414, USA. Tel: (612) 676-5414. Fax: (612) 6765743. E-mail: ruth.lynfield@health.state.mn.us

ISSN 1064-7449 print/ISSN 1098-0997 online (C) 2005 Taylor \& Francis Group Ltd DOI: $10.1080 / 02656730400025594$ 
mented [8-10]. Approximately 2500 severe infections and 500 deaths due to listeriosis occur annually, and it is second only to salmonellosis in fatalities related to food-borne illness in the USA [11]. In US pregnant women, listeriosis and toxoplasmosis are the most clinically significant foodborne diseases.

In 2002, the American College of Obstetricians and Gynecologists (ACOG) collaborated with the Centers for Disease Control and Prevention (CDC) to survey pregnant women across the USA. In 2003, the Minnesota Department of Health $(\mathrm{MDH})$ conducted a similar survey of pregnant women in Minnesota using the same questionnaire. We present here the results of both surveys, comparing data specific to Minnesota with similar data from the nationwide survey.

\section{Methods}

In the fall of 2002, ACOG through its Collaborative Ambulatory Research Network (CARN), which is made up of practicing obstetrician-gynecologists, surveyed pregnant women across the USA. Participating physicians were asked to recruit up to 5 volunteer pregnant women from their practice to complete the survey. From the national $\mathrm{CDC} /$ ACOG study, 403 women were interviewed. $\mathrm{MDH}$ surveyed pregnant women in collaboration with the Women Infants and Children programs of ten local public health agencies, as well as four large multispecialty group practices that offered prenatal care services. A geographical sampling scheme was used to ensure that the study sample was representative of all women of childbearing age in the state. In Minnesota, 286 pregnant women completed the survey. Both surveys involveded the same data collection instrument although the sampling schemes were different. Therefore, the respondents were demographically representative of their respective target populations but they were not similar to each other.

The survey was developed by $\mathrm{MDH}$, with input from staff at CDC and ACOG. Infectious disease physicians, public health physicians, veterinarians, health educators, and laboratorians contributed to the development of the survey instrument. The survey collected demographic information as well as information on pregnant women's knowledge of the transmission, risk factors, symptoms and prevention of listeriosis. The survey collected no personal identifying information and took approximately 20 min to complete. The study was exempted from full committee review by the human subjects review boards of all three collaborating institutions. The survey was piloted among non-medical staff of CDC and by ACOG obstetricians. Because of the different study populations, and to avoid introducing sampling bias resulting from over representation of Minnesota residents, we performed a comparative rather than a combined analysis of the responses. Data from the surveys were analyzed using simple random sample techniques. Univariate and stratified analyses were conducted in Epi Info version 2002.

\section{Results}

A total of 403 pregnant women were surveyed by 225 CARN physician members. The subjects ranged in age from 12 to 49 years (mean 29 years). Respondents to the CDC/ACOG survey were well dispersed across the four regions of the country but were more likely to be white, educated, and to live in rural locations than the general US population. A total of 286 pregnant women were surveyed by $\mathrm{MDH}$, ranging in age from 15 to 42 years (mean 25 years). Respondents to the $\mathrm{MDH}$ survey were geographically and racially similar to the state population, with approximately half (46\%) residing in rural areas and the majority being white. However, $12 \%$ of respondents considered themselves to be of Hispanic ethnicity, compared with $3 \%$ of the state population.

Respondents in both studies were predominantly white, non-Hispanic, and born in the USA, but there were several differences (Table I). The CDC/ACOG study population tended to be more educated and less rural than the $\mathrm{MDH}$ study population: $82 \%$ of women in the national survey had some college education compared with $49 \%$ in Minnesota $(p<0.01)$, and $33 \%$ of respondents to the $\mathrm{CDC} /$ ACOG survey resided in rural areas compared with $46 \%$ in the $\mathrm{MDH}$ survey $(p=0.05)$.

Survey questions on listeriosis were divided into two sections; the first section covered knowledge of transmission and symptoms of listeriosis, and the second section focused on preventive behavior. Among survey respondents, knowledge about listeriosis was generally lacking; only 74 (18\%) of 403 respondents to the CDC/ACOG survey and 43 (15\%) of 286 respondents to the $\mathrm{MDH}$ survey indicated that they had ever read, heard or seen any information about listeriosis. Of these, the majority reported hearing about it from a medical professional or in magazines and books about childbirth. Less frequently, friends and family, health classes and television were the source of information. The least likely sources of listeriosis information were government agencies (Table II). Table III compares the responses to selected questions: respondents to the CDC/ACOG survey were more likely to choose the correct answers compared with respondents to the $\mathrm{MDH}$ survey. Of the nationwide respondents, $33 \%$ compared with $17 \%$ in Minnesota $(p=0.01)$ 
Table I. Demographic characteristics of participants.

\begin{tabular}{|c|c|c|c|}
\hline $\begin{array}{l}\text { Demographic } \\
\text { information }\end{array}$ & $\begin{array}{l}\text { Minnesota, } \\
n=286(\%)\end{array}$ & $\begin{array}{c}\text { National, } \\
n=403(\%)\end{array}$ & $p$ Value \\
\hline \multicolumn{4}{|l|}{ Age } \\
\hline$\leqslant 25$ years & 58 & 30 & \\
\hline $26-34$ years & 36 & 57 & \\
\hline$\geqslant 35$ years & 6 & 13 & $<0.01$ \\
\hline \multicolumn{4}{|l|}{ Education } \\
\hline $\begin{array}{l}\text { some high school/ } \\
\text { graduate }\end{array}$ & 51 & 18 & \\
\hline some college/graduate & 48 & 65 & \\
\hline graduate school & 1 & 17 & $<0.01$ \\
\hline \multicolumn{4}{|l|}{ Residence } \\
\hline rural & 46 & 33 & \\
\hline suburban & 35 & 53 & \\
\hline urban & 18 & 15 & 0.05 \\
\hline \multicolumn{4}{|l|}{ Race } \\
\hline American Indian & 6 & 0 & \\
\hline Asian & 3 & 5 & \\
\hline Black & 2 & 9 & \\
\hline White & 81 & 79 & \\
\hline other & 8 & 7 & 0.03 \\
\hline Born in USA & 95 & 84 & 0.01 \\
\hline \multicolumn{4}{|l|}{ Trimester of pregnancy } \\
\hline 1 & 26 & 19 & \\
\hline 2 & 33 & 22 & 0.04 \\
\hline 3 & 41 & 59 & \\
\hline Primiparous & 52 & 38 & 0.05 \\
\hline
\end{tabular}

Table II. Sources of listeriosis information among survey respondents who indicated knowledge of listeriosis.

\begin{tabular}{lcc}
\hline $\begin{array}{l}\text { `ources of } \\
\text { listeriosis knowledge }\end{array}$ & $\begin{array}{c}\text { Minnesota, } n=43 \\
(\%)\end{array}$ & $\begin{array}{c}\text { National, } n=74 \\
(\%)\end{array}$ \\
\hline $\begin{array}{l}\text { Medical professional } \\
\text { Magazines/books on }\end{array}$ & $36(86)$ & $37(50)$ \\
childbirth & $27(64)$ & $44(60)$ \\
Friends/family & $11(26)$ & $17(23)$ \\
Health class/lecture & $7(17)$ & $16(22)$ \\
Television & $6(14)$ & $12(16)$ \\
Childbirth class & $7(17)$ & $6(8)$ \\
Government agency & $2(5)$ & $2(3)$ \\
\hline
\end{tabular}

$\star$ Percentages do not add up to $100 \%$ because instructions were to check all opinions that applied.

knew listeriosis could be prevented by avoiding delicatessen meats and soft cheeses, whereas 31\% nationwide compared with $19 \%$ in Minnesota $(p=0.05)$ knew the infection could be prevented by avoiding unpasteurized dairy products. The behavior questions were designed to assess dietary habits and handwashing after various activities. The majority of participants in both cohorts responded appropriately to questions about hand hygiene, but only $14 \%$ of
CDC/ACOG respondents and $18 \%$ of $\mathrm{MDH}$ respondents reported avoiding delicatessen and readyto-eat foods. There were no statistically significant trends in knowledge levels or behavior by race, age group, level of education, trimester of pregnancy or number of pregnancies. This was true even after combining the responses to both surveys to reduce the effect of sample size.

\section{Discussion}

The results of these surveys show a general lack of knowledge about listeriosis among women of childbearing age in the USA. Although not a particularly common disease in the general population, listeriosis does have important clinical relevance to pregnant women and their newborns, and healthcare professionals should provide appropriate prenatal education about it to their clients. Most pregnant women (86\% in Minnesota and 50\% in the CDC/ ACOG survey) who had some previous knowledge of listeriosis reported receiving this information from a medical professional. Other significant sources of listeriosis information were health classes, magazines and books on childbirth, and television. Government agencies were the least likely source of information reported by both cohorts; only 3\% and $5 \%$ of pregnant women in the CDC/ACOG and $\mathrm{MDH}$ surveys, respectively, indicated that they had heard of listeriosis from a government agency. However, it is possible that much of the information from these other sources originated from a government agency or was produced with government funding. Overall, less than $30 \%$ of women surveyed knew that listeriosis could be prevented by avoiding delicatessen meats, soft cheeses and unpasteurized dairy products, and less than $20 \%$ actually avoided delicatessen and ready-to-eat foods while pregnant. This is significant, because up to $4.7 \%$ of all readyto-eat foods may be contaminated with $L$. monocytogenes [12].

In addition to the overall lack of knowledge about listeriosis among pregnant women in the USA evident from this survey, the differences in the responses of each study population are also significant. We were unable to detect any trends in knowledge levels by age, race, educational levels, number or trimester of pregnancy, even after combining the data. However, a 1999 survey of new mothers in Western Australia showed that younger women, women in their first pregnancy, and women with lower education levels tended to have lower levels of listeriosis knowledge and might be at increased risk for exposure to L. monocytogenes during pregnancy [3]. In the Australian survey, 89\% of respondents had heard of listeriosis. The $11 \%$ who had not heard of it were more likely to be young 
Table III. Correct responses to selected listeriosis questions.

\begin{tabular}{|c|c|c|c|}
\hline Selected questions & $\begin{array}{l}\text { Minnesota } \\
(\%)\end{array}$ & $\begin{array}{l}\text { National } \\
(\%)\end{array}$ & $p$ Value \\
\hline $\begin{array}{l}\text { Have you ever seen, heard } \\
\text { or read information on } \\
\text { listeriosis? }\end{array}$ & 15 & 18 & 0.28 \\
\hline \multicolumn{4}{|l|}{ Listeriosis is caused by: } \\
\hline ^allergies & 15 & 27 & 0.04 \\
\hline${ }^{\star}$ swimming in dirty water & 10 & 20 & 0.05 \\
\hline germs in raw food & 24 & 31 & 0.23 \\
\hline$\star_{\text {tick bite }}$ & 13 & 20 & 0.18 \\
\hline \multicolumn{4}{|l|}{ Listeriosis: } \\
\hline $\begin{array}{l}\text { can spread from infected } \\
\text { sheep to people }\end{array}$ & 3 & 8 & 0.12 \\
\hline $\begin{array}{l}\text { usually does not cause } \\
\text { illness }\end{array}$ & 6 & 14 & 0.06 \\
\hline $\begin{array}{l}\text { can be passed from } \\
\text { pregnant woman to baby }\end{array}$ & 23 & 33 & 0.12 \\
\hline can cause a fever in babies & 13 & 18 & 0.33 \\
\hline \multicolumn{4}{|l|}{ Ways to avoid getting } \\
\hline $\begin{array}{l}\text { avoid deli meats and soft } \\
\text { cheeses }\end{array}$ & 17 & 33 & 0.01 \\
\hline $\begin{array}{l}\text { thoroughly reheat all } \\
\text { leftover foods }\end{array}$ & 20 & 29 & 0.14 \\
\hline $\begin{array}{l}\text { eat only properly } \\
\text { pasteurized dairy foods }\end{array}$ & 19 & 31 & 0.05 \\
\hline $\begin{array}{l}{ }^{\star} \text { avoid wooded areas } \\
\text { where ticks live }\end{array}$ & 8 & 13 & 0.25 \\
\hline \multicolumn{4}{|l|}{$\begin{array}{l}\text { Since becoming pregnant } \\
\text { do you: }\end{array}$} \\
\hline${ }^{\star}$ eat rare meat & 92 & 92 & 0.80 \\
\hline $\begin{array}{l}\text { ^eat unpasteurized dairy } \\
\text { products }\end{array}$ & 88 & 86 & 0.67 \\
\hline $\begin{array}{l}{ }^{\star} \text { eat deli-style and ready- } \\
\text { to-eat foods }\end{array}$ & 23 & 18 & 0.38 \\
\hline ^eat raw vegetables & 18 & 14 & 0.44 \\
\hline
\end{tabular}

${ }^{\star}$ Correct answer is No.

single mothers, to live in rural areas, to speak a foreign language at home, or to have less formal education. The study concluded that these groups of women should be particularly targeted for educational intervention.

Several government agencies, including CDC, the Food and Drug Administration, and the United States Department of Agriculture (USDA) Food Safety and Inspection Service, are involved in listeriosis prevention efforts. These activities have resulted in an estimated $44 \%$ decline in the incidence of perinatal listeriosis, from 1989 to 1993 [14]. In 1999, CDC in collaboration with $\mathrm{MDH}$ produced a brochure for pregnant women, entitled "What you can do to keep germs from harming you and your baby", that included information on listeria. In 2001, the USDA collaborated with other agencies to produce a patient education sheet, "Listeriosis and pregnancy: what is your risk?", which targeted both pregnant women and their healthcare providers. Both of these educational materials are also available in Spanish. In light of these interventions and the media attention drawn by recent multistate listeriosis outbreaks, it is interesting that $82 \%$ to $85 \%$ of pregnant women still have never heard of the disease.

Susceptible individuals can further reduce their listeriosis risk by implementing simple precautions, many of which apply to all food-borne illnesses. These include cooking all raw meat to proper temperatures, keeping raw meat separate from cooked foods and ready-to-eat foods, avoiding consumption of unpasteurized dairy products, and promptly refrigerating all prepared foods and leftovers. It is also important to wash hands, kitchen surfaces and utensils thoroughly after contact with uncooked foods. Listeriosis-specific precautions include reheating (or completely avoiding if immunocompromised) all ready-to-eat foods until steaming hot, and avoiding refrigerated meat spreads, smoked seafood, and soft cheeses such as feta, Brie, Camembert, blue-veined cheeses and Mexican-style cheeses. If timely and appropriate education about listeriosis is provided to all pregnant women, it is likely that more cases of perinatal infection could be prevented. More effort must be directed to providing information to pregnant women on minimizing exposure to listeria.

\section{Acknowledgements}

This study was supported in part by funding provided through a cooperative agreement with the Centers for Disease Control and Prevention as part of the Emerging Infections Program Network. This research was also supported in part by an appointment to the Research Participation Program at the Centers for Disease Control and Prevention, National Center for Infectious Diseases, Division of Parasitic Diseases administered by the Oak Ridge Institute for Science and Education through an interagency agreement between the US Department of Energy and CDC. Finally, we acknowledge our gratitude to the nursing staff and WIC programs of several local public health agencies and prenatal clinics in Minnesota that assisted with the data collection.

\section{References}

1. Schlech III WF. Listeriosis: epidemiology, virulence and the significance of contaminated foodstuffs. J Hosp Infect 1991;19:211-224. 
2. Dalton CB, Austin CC, Sobel J, et al. An outbreak of gastroenteritis and fever due to Listeria monocytogenes in milk. N Engl J Med 1997;336:100-105.

3. Lorber B. Listeriosis. Clin Infect Dis 1997;24:1-9.

4. Smith JL. Food borne infections during pregnancy. J Food Prot 1999;62:818-829.

5. Bortolussi R, Schlech WF. Listeriosis. In: Remington JS, Klein JO, editors. Infectious diseases of the fetus and newborn infant. 5th ed. Philadelphia, USA: Saunders; 2001. pp 1157 1177.

6. Silver HM. Listeriosis during pregnancy. Obstet Gynecol Surv 1998;53:737-740.

7. Rocourt J, Bille J. Food borne listeriosis. World Health Stat Q 1997;50:67-73.

8. Graham JC, Lanser S, Bignardi G, et al. Hospital-acquired listeriosis. J Hosp Infect 2002;51:136-139.

9. Schuchat A, Lizano C, Broome CV, et al. Outbreak of neonatal listeriosis associated with mineral oil. Pediatr Infect Dis J 1991;10:183-189.
10. Barbuddhe SB, Kumar P, Malika SV, et al. Seropositivity for intracellular bacterial infections among abattoir associated personnel. J Commun Dis 2000;32:295-299.

11. Mead PS, Slutsker L, Dietz V, et al. Food-related illness and death in the USA. Emerg Infect Dis 1999;5:607-625.

12. Gombas DE, Chen Y, Clavero RS, et al. Survey of Listeria monocytogenes in ready-to-eat foods. J Food Prot 2003;66:559569.

13. Torvaldsen S, Kurinczuk JJ, Bower C, et al. Listeria awareness among new mothers in Western Australia. Aust $\mathrm{N} Z \mathrm{~J}$ Public Health 1999;23:362-367.

14. Tappero JW, Schuchat A, Deaver KA, et al. Reduction in the incidence of human listeriosis in the USA. Effectiveness of prevention efforts? The Listeriosis Study Group. JAMA 1995;273:1118-1122. 


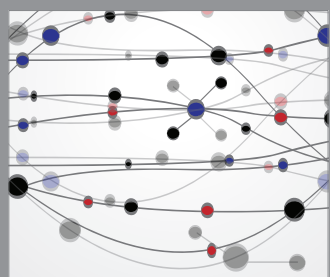

The Scientific World Journal
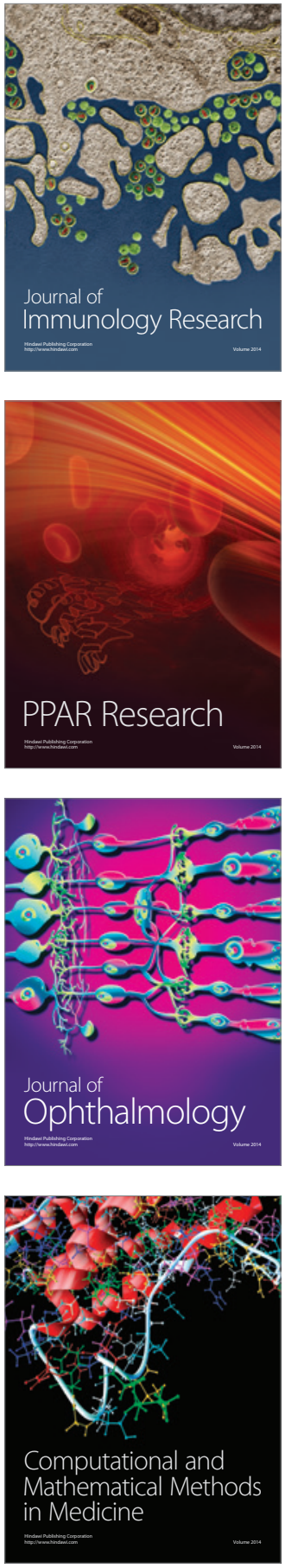

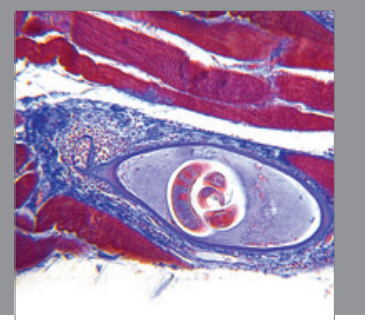

Gastroenterology

Research and Practice
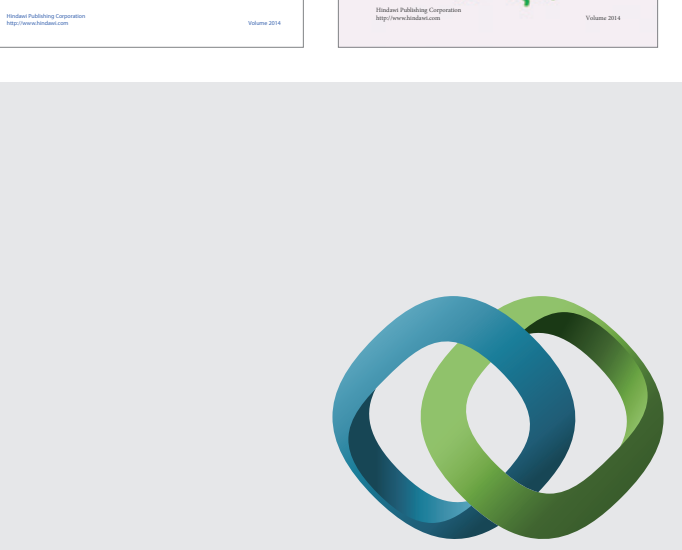

\section{Hindawi}

Submit your manuscripts at

http://www.hindawi.com
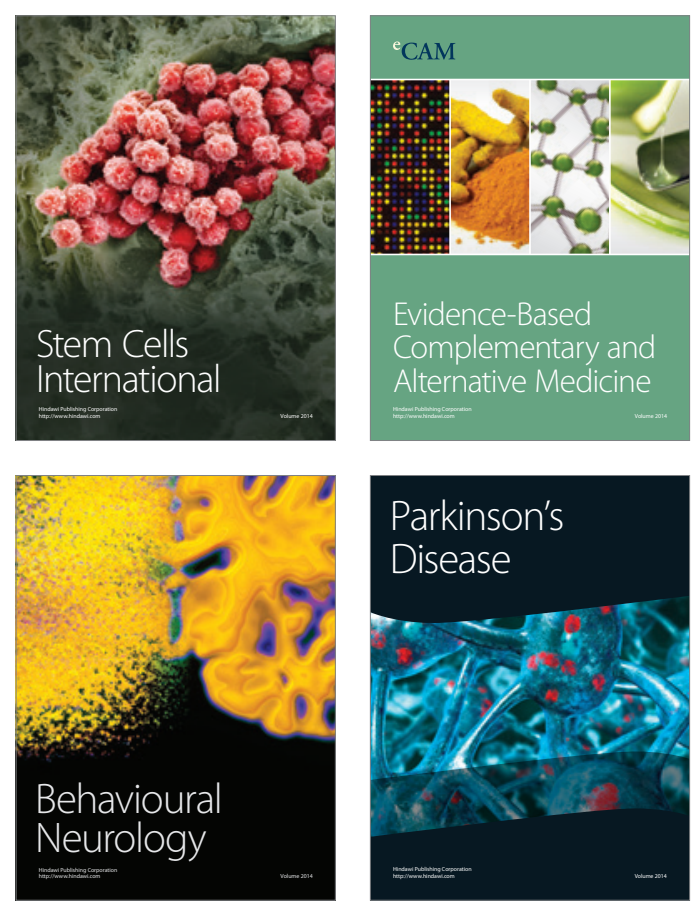

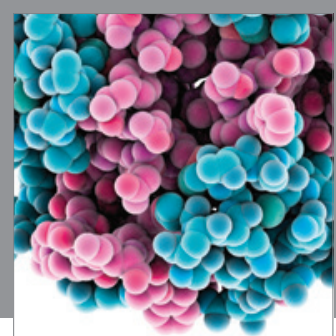

Journal of
Diabetes Research

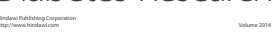

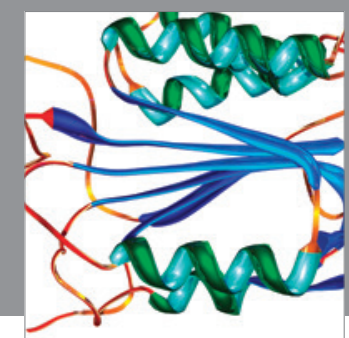

Disease Markers
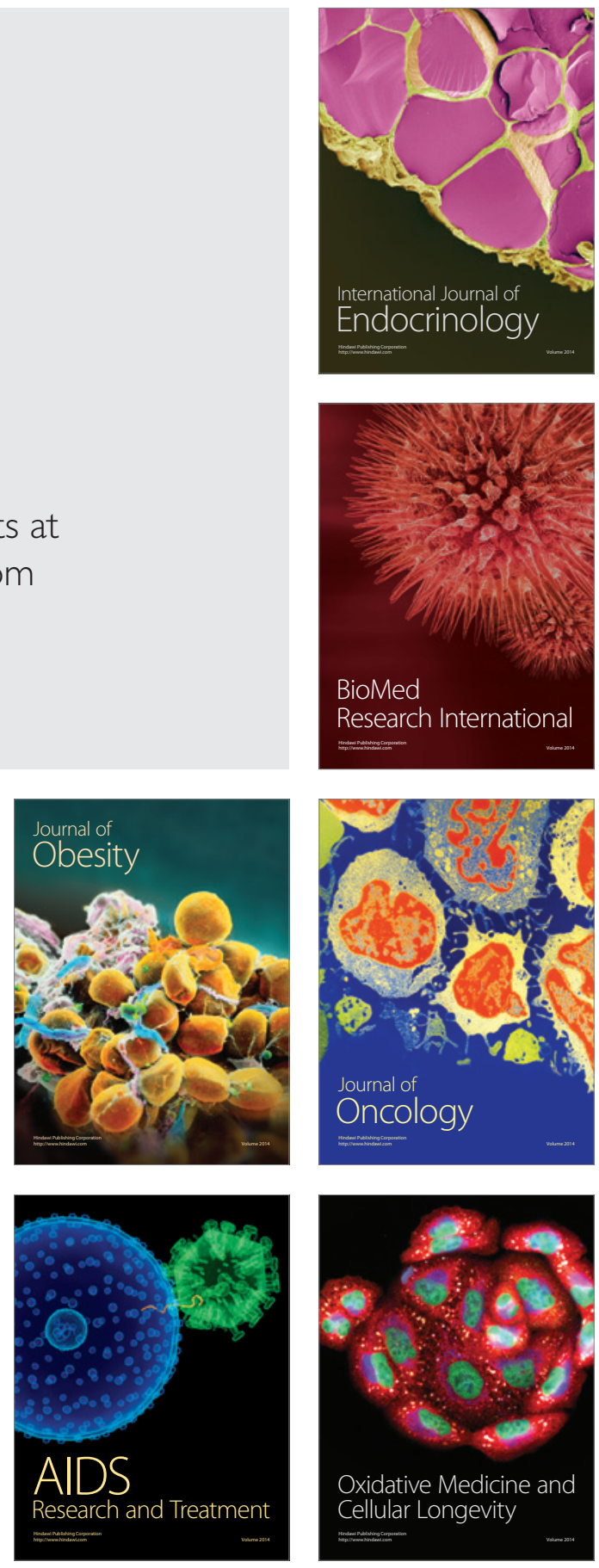